\title{
RELATIONSHIP BETWEEN INSTRUMENTAL AND SENSORY TEXTURE PROFILE OF BREAD LOAVES MADE WITH WHOLE-WHEAT FLOUR AND FAT REPLACER
}

\author{
PATRÍCIA MATOS SCHEUER ${ }^{1,5}$, MARCO DI LUCCIO², ANDRÉ WÜST ZIBETTI³, \\ MARTHA ZAVARIZ de MIRANDA ${ }^{4}$ and ALICIA de FRANCISCO ${ }^{1}$ \\ ${ }^{1}$ Cereal Laboratory, ${ }^{2}$ Food Engineering, ${ }^{3}$ Centro Tecnológico - CTC, Federal University of Santa Catarina, Rodovia Admar Gonzaga, 1346 - \\ Itacorubi, Florianópolis, SC 88040-900, Brazil \\ ${ }^{4}$ Grain Quality Laboratory, Brazilian Corporation for Agricultural Research - Embrapa Wheat, Passo Fundo, RS, Brazil
}

\section{KEYWORDS}

Bread, fat replacer, sensory trained panel, texture profile, whole-wheat flour

${ }^{5}$ Corresponding author

TEL: 55-48-37215369/ 5397;

FAX: 55-48-37215369/5397;

EMAIL: patriciamatosscheuer@gmail.com

Received for Publication May 5, 2015 Accepted for Publication August 7, 2015 Published online Article Accepted on August 13, 2015

doi:10.1111/jtxs.12155

\begin{abstract}
Food texture is one of the most widely measured quality attributes during processing and consumption, being measured by instrumental and sensory means. The aims of this study were to measure the textural parameters of the crumb of 14 whole-wheat bread loaves made with whole-wheat flour and fat replacer using instrumental methods and a sensory trained panel, and to determine the relationship between instrumental and sensory assessments. The data of instrumental and sensory texture were individually subjected to analysis of variance and correlated using principal component analysis. The analyses showed that for both (instrumental and sensory texture), the less firm, more elastic and more cohesive bread loaves have $<60 \%$ whole-wheat flour, regardless of the content of fat replacer. The hardness attribute, measured with a texturometer, was consistent with the results of other published works and with our sensory evaluation as the matrix showed correlation coefficients with high values.
\end{abstract}

\section{PRACTICAL APPLICATIONS}

Wheat bread is a common staple food around the world that can be used to deliver ingredients for specific health purposes. Diets rich in whole grain foods and low fat may be suggested to help to protect against several chronic diseases, as well as for weight management. At a pilot plant scale, it is very difficult to keep good quality standards for whole-wheat products. Therefore, instrumental and sensory studies on loaf texture were used to perform texture profile analysis on the crumb structure of 14 different types of whole-wheat bread loaves made with fat replacer (enzymatically modified corn starch).

\section{INTRODUCTION}

Food texture is one of the most widely measured quality attributes during processing and consumption. Texture can be measured by means of objective (instrumental) and intrinsic subjective (sensory) tests (Szczesniak 1963).
Among the instrumental test devices, texturometers imitate mastication condition and present excellent correlation with sensory evaluation of texture (Szczesniak 1963). For this reason, they have been widely used to measure texture of different kinds of food. Instrumental measurements are usually cheaper and easier to achieve and thus represent an interesting alternative to the sensory 
measurement of texture, provided that instrumental data can be related to sensory description. So, these instrumental measurements could be used to monitor bread quality during processing and storage (Lassoued et al. 2008).

Regarding sensory analysis in the mouth, the characteristics perceived include mechanical attributes (relating to the reaction to the applied force), geometrical attributes (relating to the shape, size and particle orientation inside the food) and attributes relating to perception of moisture or fat content (Szczesniak 2002). According to Lassoued et al. (2008), sensory evaluation is seldom used in baking industry, mostly because of cost, necessary time for training and managing a sensory panel, and difficulty in running a sensory evaluation of bread loaves made at a laboratory scale.

The accuracy of an objective method to measure a quality attribute of food is only determined by its correlation to the sensory evaluation of that attribute (Kokini 1985). Correlation between sensory and instrumental measurements of texture results in (1) finding instruments to measure quality control of food in industries; (2) predicting consumer response, as the degree of liking and the overall acceptance of a new product; (3) understanding what is being sensed and perceived in the mouth during the sensory assessment of texture; and (4) improving or optimizing instrumental methods to complement sensory evaluation (Szczesniak 1987).

The development of safer and healthier low-calorie products with acceptable functional and sensory characteristics (Collar et al. 2007) is demanded by customers a little more each day (Gómez et al. 2002).

Dietary fiber increases the nutritional value of bread but usually at the same time it alters the rheological properties of dough and bread sensory properties and quality (Gómez et al. 2002). Despite that dietary fiber has been proven to provide several beneficial metabolic and physiological effects, fiber replacement of wheat flour disrupts starchgluten matrix and restricts gas cells to expand, affecting specific bread volume and crumb hardness (Rosell and Santos 2010), such as from the use of whole-wheat flour (WF) in breads (Seyer and Gélinas 2009).

While lipids lubricate and plasticize dough in the bread, in particular gluten polymers (Mehta et al. 2009), fat should be restricted or reduced in the diet because it is the most important obesity factor (Valenzuela and Sanhueza 2008) and noncommunicable chronic disease factor (Brasil 2005). Therefore, carbohydrate-based fat replacers (FRs) are able to stabilize substantial amounts of water, as a gel-like matrix. Such a property makes carbohydrate-based FRs similar to fats (Lucca and Tepper 1994). This can be observed in breads: sodium alginate, xanthan, kcarrageenan, hydroxypropyl methylcellulose (Guarda et al. 2004); modified starches (Miyazaki et al. 2006); inulin, simplesse (whey protein) (O’Brien et al. 2003); inulin, pectin, guar gum (Skara et al. 2013).

Principal component analysis (PCA) is a method of projection and dimensional data reduction (Krbi et al. 2005), in which there is an association between analyses in order to verify the degree of participation of each of them (Heenan et al. 2008), such as WF and FR in the instrumental and sensory texture parameters of breads.

It is intended to replace a set of correlated variables, a set of new uncorrelated variables, and being these linear combinations of the initial variables placed in descending order by their variances (Lopes 2001).

There is no research on bread loaves made with WF and FR, so the aims of this study were (1) to measure the textural parameters of a set of 14 whole-wheat bread crumbs made with WF and FR, using instrumental methods and a sensory trained panel, and (2) to determine the relationship between instrumental and sensory assessments.

\section{MATERIALS AND METHODS}

\section{Materials}

The study was conducted with commercial samples of WF and white flour (IF), obtained from the same batch of wheat, harvested 2012, provided by Cooperativa Agrária Agroindustrial, Guarapuava, state of Paraná, Brazil. These samples were stored at $-18 \mathrm{C}$ until time of analysis. Aiming to promote the standardization and the study of the dependent variables, a representative sample of each type of flour (WF and IF) was used.

Modified corn starch by enzymatic conversion, commercially suitable for the preparation of bread, was used as a FR, donated by Dutch Starches International - DSI, the Netherlands, brand name Selectamyx C150.

\section{Methods}

Bread Samples. For preparation of the bread loaves, WF and IF mixtures were prepared and samples were coded according to the percentage used: 95.35WF $(95.35 \mathrm{WF}+$ 4.65IF); 85WF (85WF + 15IF); 60WF (60WF + 40IF); 35WF $(35 \mathrm{WF}+65 \mathrm{IF}) ; 24.64 \mathrm{WF}(24.64 \mathrm{WF}+75.36 \mathrm{IF})$ according to experimental design of the response surface methodology (RSM).

Bread loaves were prepared on a pilot scale and randomly selected twice according to the optimized straight-dough bread-making method (10-10B) (AACC International 2000 ), with a $60-$ min fermentation. Formulation was modified. The same level of ingredients method was as follows: wheat flour $(100 \%)$, sucrose $(6 \%)$, instant active dry yeast $(1.8 \%)$, sodium chloride $(1.5 \%)$, FR $(3 \%)$ and tap water, according to Flander et al. (2007). The amount of water 
used corresponded to $86 \%$ of the water absorption content as determined by Farinograph analysis (method adapted from Seyer and Gélinas 2009). The ingredients were mixed at speed setting 2 for 6 min (Flander et al. 2007; Oro 2013) in a commercial mixer (RPD 25, Líder, Curitiba, Brazil). Dough temperature was kept at 28-29C after mixing. Subsequently, 500-g pieces of dough were placed in a proofing cabinet (CFC20, Perfecta, Curitiba, Brazil) at 30C and $85 \%$ relative humidity for $35 \mathrm{~min}$. Dough was then kneaded once, fermented for $17 \mathrm{~min}$, kneaded again and fermented for further $8 \mathrm{~min}$. Dough was sheeted manually, placed into a rectangular mold $(9.5 \times 20 \times 4.5 \mathrm{~cm})$ and fermented for 24 min. Finally, dough was baked in an electric oven (Ventile, Líder, Curitiba, Brazil) for $24 \mathrm{~min}$ at $180 \mathrm{C}$ and cooled for $1 \mathrm{~h}$ at room temperature on metal racks.

Experimental Design. The experiment was designed using the rotatable central composite design of RSM, a wellestablished statistical procedure (Box and Draper 2007). It is widely applied to research on bread where there is replacement of some ingredients to design enriched fiber and lowcalorie wheat bread formulation [wheat bran, resistant starch and locust bean gum (Almeida et al. 2013); inulin, sugar beet, pea cell wall, pea hull (Collar et al. 2007); inulin, pectin or guar gum (Skara et al. 2013)].

The rotatable central composite design yielded 14 experiments as follows: four factorial treatments, in which two factors were \%WF (percentage of whole-wheat flour) and $\%$ FR (percentage of fat replacer), each with two levels coded to -1 and +1 ; four axial treatments including minimum and maximum levels of each factor coded as $-\alpha$ and $+\alpha$, where $\alpha=\left(2^{2}\right)^{1 / 4}=1.414$; and one central treatment repeated six times, to estimate pure experimental error and calculate method reproducibility, in which all factors are coded as zero. The real values of the two variables are shown in Table 1.

\section{Bread Texture Profile Evaluation}

Instrumental. Crumb texture profile analysis (TPA) was performed on eight 25-mm cubes from the center of each loaf, according to method 74-10A (AACC International 2000). Four textural parameters were extracted from the curves: hardness, springiness, cohesiveness and chewiness. According to Szczesniak (2002), hardness is the force necessary to attain a given deformation; springiness is the rate at which a deformed material returns to the undeformed condition after deforming force is removed; cohesiveness is the strength of the internal bonds making up the body of the product; and chewiness is the energy required to masticate a solid product to a state ready for swallowing.

TPA was measured in duplicate with Texture Analyzer TA-XT Plus (Stable Micro System, Surrey, U.K.) equipped with a $50-\mathrm{kg}$ load cell and a $36-\mathrm{mm}$ aluminum cylindrical
TABLE 1. BREAD COMPOSITION

\begin{tabular}{cccc}
\hline & & \multicolumn{2}{c}{ Independent variables } \\
\cline { 3 - 4 } Loaf & Treatment & $\%$ WF & $\% \mathrm{FR}$ \\
\hline 1 & Factorial & 35.00 & 0.60 \\
2 & & 35.00 & 2.60 \\
3 & & 85.00 & 0.60 \\
4 & & 85.00 & 2.60 \\
5 & Axial & 24.64 & 1.60 \\
6 & & 95.35 & 1.60 \\
7 & 60.00 & 0.18 \\
8 & & 60.00 & 3.00 \\
9 & & 60.00 & 1.60 \\
10 & Central & 60.00 & 1.60 \\
11 & & 60.00 & 1.60 \\
12 & & 60.00 & 1.60 \\
13 & & 60.00 & 1.60 \\
14 & & 60.00 & 1.60 \\
\hline
\end{tabular}

FR, fat replacer (enzymatically modified corn starch); WF, whole-wheat flour.

probe, which underwent two double compression tests up to $40 \%$ penetration of the original height (10 $\mathrm{mm}$ distance) at a crosshead speed of $2 \mathrm{~mm} / \mathrm{s}$ with a 5 -s gap between sample compressions (Oro 2013).

For the results of the central treatment points, only the mean of the values from samples 9 to 14 will be discussed.

Sensory. Quantitative descriptive analysis of the sensory texture profile of bread crumb started after approval by CEP/Conep (Comitê de Ética em Pesquisa/Comissão Nacional de Ética em Pesquisa).

From the 50 interested members, following the methodology described by Civille and Szczesniak (1973), 21 volunteers were recruited, mostly federal employees of the Campus Florianópolis-Continent belonging to Federal Institute of Education, Science and Technology of Santa Catarina (IFSC), who were regular wheat bread consumer.

The training of $40 \mathrm{~h}$, divided into fortnightly sessions lasting an average of $2 \mathrm{~h}$, was divided into two steps: (1) general aspects, technical and sensory analysis; and (2) specific knowledge of the sensory texture profile directed to evaluate bread crumb. Training was conducted at IFSC Food and Beverages laboratories and the sensory analysis, with adapted sensory booths and scale adjustment notes for the expression of results for the panelists. At the end of training, 12 panelists were selected.

Samples were cut into $25-\mathrm{mm}$ edge cubes (Flander et al. 2007), similar to Elía's (2011) study, with a 20-mm cube edge.

Analysis was performed within 2 days. Adopting orthogonal block design (Fisher 1918), which aims to eliminate the effect of this heterogeneity in the experimental units of treatment comparison, from 14 total types of breads, with six repetitions at the central point, only 12 types of bread 
TABLE 2. INSTRUMENTAL TEXTURE PARAMETERS

\begin{tabular}{|c|c|c|c|c|c|c|}
\hline Sample bread loaf & WF (\%) & FR (\%) & Hardness (N) & Elasticity $(\mathrm{mm})$ & Cohesiviness & Chewiness (J) \\
\hline 1 & 35.00 & 0.60 & $11.56^{f} \pm 0.95$ & $0.781^{a} \pm 0.061$ & $0.598^{a} \pm 0.018$ & $5.42^{\mathrm{bcd}} \pm 0.83$ \\
\hline 2 & 35.00 & 2.60 & $11.21^{\dagger} \pm 1.50$ & $0.757^{\mathrm{ab}} \pm 0.046$ & $0.600^{a} \pm 0.023$ & $5.12^{\mathrm{cd}} \pm 1.01$ \\
\hline 3 & 85.00 & 0.60 & $29.56^{a} \pm 1.13$ & $0.572^{\mathrm{ef}} \pm 0.042$ & $0.487^{e f} \pm 0.016$ & $8.27^{\mathrm{a}} \pm 1.08$ \\
\hline 4 & 85.00 & 2.60 & $22.77^{b} \pm 2.12$ & $0.591^{\mathrm{ef}} \pm 0.037$ & $0.513^{\text {cdef }} \pm 0.032$ & $6.91^{\mathrm{ab}} \pm 0.81$ \\
\hline 5 & 24.64 & 1.60 & $8.40^{f} \pm 1.31$ & $0.785^{a} \pm 0.039$ & $0.606^{a} \pm 0.027$ & $4.00^{\mathrm{de}} \pm 0.73$ \\
\hline 6 & 95.35 & 1.60 & $29.86^{a} \pm 2.61$ & $0.543^{f} \pm 0.020$ & $0.484^{\dagger} \pm 0.016$ & $7.87^{\mathrm{a}} \pm 0.88$ \\
\hline 7 & 60.00 & 0.18 & $19.17^{\mathrm{cd}} \pm 2.49$ & $0.603^{\text {def }} \pm 0.060$ & $0.506^{\mathrm{def}} \pm 0.029$ & $5.91^{b c} \pm 1.32$ \\
\hline 8 & 60.00 & 3.00 & $16.53^{\mathrm{de}} \pm 1.67$ & $0.654^{c d} \pm 0.029$ & $0.537^{\mathrm{bcd}} \pm 0.019$ & $5.83^{\mathrm{bc}} \pm 0.84$ \\
\hline 9 & 60.00 & 1.60 & $15.58^{\mathrm{e}} \pm 2.51$ & $0.442^{9} \pm 0.050$ & $0.440^{9} \pm 0.030$ & $3.02^{e} \pm 0.61$ \\
\hline 10 & 60.00 & 1.60 & $16.06^{\mathrm{de}} \pm 2.14$ & $0.564^{e f} \pm 0.048$ & $0.515^{\text {cdef }} \pm 0.030$ & $4.74^{\mathrm{cd}} \pm 1.26$ \\
\hline 11 & 60.00 & 1.60 & $20.42^{\mathrm{bc}} \pm 2.69$ & $0.625^{\text {cde }} \pm 0.046$ & $0.540^{\mathrm{bcd}} \pm 0.027$ & $6.95^{\mathrm{ab}} \pm 1.47$ \\
\hline 12 & 60.00 & 1.60 & $20.46^{b c} \pm 1.36$ & $0.687^{b c} \pm 0.026$ & $0.579^{\mathrm{ab}} \pm 0.022$ & $8.13^{\mathrm{a}} \pm 0.71$ \\
\hline 13 & 60.00 & 1.60 & $16.91^{\text {de }} \pm 0.99$ & $0.629^{\text {cde }} \pm 0.034$ & $0.548^{b c} \pm 0.022$ & $5.84^{b c} \pm 0.62$ \\
\hline 14 & 60.00 & 1.60 & $17,21^{\mathrm{de}} \pm 1,52$ & $0,591^{\text {def }} \pm 0,032$ & $0,533^{\text {cd }} \pm 0,015$ & $5,46^{\mathrm{bcd}} \pm 0,89$ \\
\hline $9-14$ & 60.00 & 1.60 & $17.77^{\text {cde }} \pm 0.84$ & $0.590^{\text {def }} \pm 0.016$ & $0.526^{\text {cde }} \pm 0.009$ & $5.89^{b c} \pm 0.38$ \\
\hline
\end{tabular}

Mean \pm standard deviation in the same column followed by different letters are significantly different $(P \leq 0.05)$. Sample breads $9-14$ represent the average among bread loaves from 9 to 14.FR, fat replacer; WF, whole-wheat flour.

with four repetitions of the central point have been evaluated. Its purpose is to have homogeneous groups of parcels (blocks), each receiving repetition for all treatments.

For the results of the central points, only the average between them (9-12) will be discussed.

On the first day, four samples of the factorial points and two of the central points and, on the second day, four samples of the axial points and two of the central points were made available. On each day, each judge received a list of parameter definitions and six different samples, each in triplicate to evaluate each parameter. For example, three successive sets of samples were cut just before the session and presented in porcelain dish with random 3-digit code (Heenan et al. 2008). Parallel to the sensory analysis, water was served to the judges as a way to clean the palate between analyses (Heenan et al. 2008).

The evaluated attributes of sensory texture were hardness, elasticity, cohesiveness and chewiness, characterized using the definition according to Civille and Szczesniak (1973) as follows: hardness, the force required to compress a component between molar teeth; elasticity, the degree with which the product returns to its original shape after it is compressed between teeth; cohesiveness, the degree to which a component is fully compressed between teeth before rupturing; chewiness, the time required to chew a sample at a constant speed of force application to reduce it to proper consistency for swallowing.

Principal Component Analysis. The main objective of the PCA is to obtain a small number of linear combinations (major components) of a set of variables that retain as much of the information contained in the original variables as possible. Therefore, the use of PCA can be as effective as the use of the original data (Lopes 2001).

\section{Statistical Analysis}

Data were subjected to analysis of variance (ANOVA) and means were compared by Tukey's test $(P \leq 0.05)$.

The instrumental and sensory textures were correlated, valued at similarities and differences using PCA; furthermore, the correlation matrix was used, and correlation coefficients were calculated.

For statistical analysis, Statistica 7.0 Copyright StatSoft, Inc., Tulsa, OK, USA, 1984-2004, program was used.

\section{RESULTS AND DISCUSSION}

\section{Instrumental Texture Analysis}

The instrumental texture bread parameters are described in Table 2.

Hardness. Bread samples' hardness results are shown in Table 2, ranging from 8.40 to $29.86 \mathrm{~N}$, similar to the study of Collar et al. (2014) with bread enriched with cereals, pseudocereals and vegetables and similar to the study of Koletta et al. (2014) in which white flour bread has been replaced by rye whole meal flour and/or whole barley flour and/or oat bran.

Samples $3(85 \mathrm{WF}+0.60 \mathrm{FR})$ and 6 (95.35WF + 1.60FR) have significantly equal and higher hardness values (29.56 and $29.86 \mathrm{~N}$, respectively) $(P \leq 0.05)$ than other bread samples, even for sample 4 ( $85 \mathrm{WF}+2.60 \mathrm{FR})$, showing that the increase in FR provides a softer bread, the same way as hydrocolloids act as inhibiting starch retrogradation in a similar work (Li and Nie 2015).

For other samples with the same amount of WF, regardless of the amount of FR $(1[35 \mathrm{WF}+0.6 \mathrm{FR}]$ and 2 
$[35 \mathrm{WF}+2.6 \mathrm{FR}] ; 7[60 \mathrm{WF}+0.18 \mathrm{FR}], 8[60 \mathrm{WF}+3 \mathrm{FR}]$ and 9-14 $[60 \mathrm{WF}+1.6 \mathrm{FR}])$, there was no significant difference in hardness parameter. This demonstrated that high levels of WF mask the different levels of fat replacement. Different behaviors found in an unleavened Indian bread made of $\mathrm{WF}, \mathrm{w}$ ith the addition of $0.75 \%$ guar gum of WF, resulted in a softer bread than the one without hydrocolloid (Shalini and Laxmi 2007), probably because it is a flat bread, with little crumb surface.

Sample bread $5(24.64 \mathrm{WF}+1.6 \mathrm{FR})$, with the least amount of WF with a significantly lower hardness value, had hardness significantly lower than and equal to samples $1(35 \mathrm{WF}+0.6 \mathrm{FR})$ and $2(35 \mathrm{WF}+2.6 \mathrm{FR})$ and shown to be the softest bread loaf.

In general, there was steadily hardness increase as WF content increased. As demonstrated in a similar work, wherein bread crumb hardness increased from the substitution of white flour by whole meal flour made with intermediate fractions of wheat grain milling (Blandino et al. 2013).

However, significant differences are observed $(P \leq 0.05)$ in hardness values between samples $3(85 \mathrm{WF}+0.6 \mathrm{FR})$ and $4(85 \mathrm{WF}+2.6 \mathrm{FR})$, with the same WF content with each other and different levels of fat replacement, showing the work of enzymatically modified starch in the softness of the bread, which is not observed between samples with higher amount of white flour (1 [35WF+0.6FR] and 2 $[35 \mathrm{WF}+2.6 \mathrm{FR}] ; 7[60 \mathrm{WF}+0.18 \mathrm{FR}], 8[60 \mathrm{WF}+3 \mathrm{FR}]$ and 9-14 [60WF $+1.6 \mathrm{FR}]$, respectively). A similar result was observed with substitution of up to $20 \%$ white wheat flour of hydroxypropylated tapioca starch or acetylated tapioca starch and vital gluten, resulting in a softer bread (Miyazaki et al. 2005). This behavior can be explained, characterizing the FR as an antifirming component, such as shortening and monoglyceride, restricting starch swelling during baking. Gluten is the continuous phase, and remnants of starch granule are the discontinuous phase. During baking, antifirming components interact with wheat flour starch molecules and decrease starch swelling. With less surface area exposed to gluten, fewer and/or weaker cross-links occur with protein; therefore, firming rate is reduced (Martin et al. 1991).

Elasticity. The results of elastic bread samples (Table 2) ranged from 0.543 to $0.785 \mathrm{~mm}$, with similar values $(0.830$ $0.910 \mathrm{~mm}$ ) to breads in which inulin was incorporated in different percentages (Rubel et al. 2015).

Bread samples 1 (35WF + 0.60FR), 2 (35WF + 2.60FR) and $5(24.64 \mathrm{WF}+1.60 \mathrm{FR})$ resulted in more elastic and less hard bread loaves, having been produced with the lowest of the WF content. These loaves had significantly equal and higher values in elasticity than the other samples $(P \leq 0.05)$, regardless of the fat replacement used.
Samples $7(60 \mathrm{WF}+0.18 \mathrm{FR}), 8(60 \mathrm{WF}+3 \mathrm{FR})$ and $9-14$ $(60 \mathrm{WF}+1.6 \mathrm{FR})$ having the same content of WF and variation of an FR have substantially equal elasticity values, being $0.603,0.654$ and $0.590 \mathrm{~mm}$, respectively.

Sample $6(95.35 \mathrm{WF}+0.6 \mathrm{FR})$ has the largest WF percentage, showing elasticity equal to samples $3(85 \mathrm{WF}+0.60 \mathrm{FR})$, $4(85 \mathrm{WF}+2.60 \mathrm{FR}), 7(60 \mathrm{WF}+0.18 \mathrm{FR})$ and $9-14(60 \mathrm{WF}+$ $1.60 \mathrm{FR})$, and elasticity lower than sample $8(60 \mathrm{WF}+3 \mathrm{FR})$ $(P \leq 0.05)$. This shows that elasticity increases with the reduction of WF content and increased fat content replacement being inversely proportional.

Cohesiveness. Cohesiveness results of bread samples are shown in Table 2, ranging from 0.484 to 0.606 , similar to the bread results in which $4 \%$ hydrolyzed protein $(0.560)$ replaced white flour and control bread (0.780) (Fitzgerald et al. 2014). Cohesiveness is described as elastic behavior.

Chewiness. Bread samples chewiness results are shown in Table 2, ranging from 4.00 to $8.27 \mathrm{~J}$, with values similar (around $4.35 \mathrm{~J}$ ) to bread in which inulin was incorporated in different percentages (Rubel et al. 2015). Chewiness is described as hardness behavior (Liu et al. 2015).

Samples 3 (85WF + 0.60FR), $4(85 \mathrm{WF}+2.60 \mathrm{FR})$ and 6 $(95.35 \mathrm{WF}+1.60 \mathrm{FR})$ had significantly equal values compared to each other and superior to other samples of breads $(P \leq 0.05)$ showing that larger WF content rebound on bread chewiness. These results are in accordance with other studies using wheat flour replacement: bran wheat flour can weaken gluten network and, being composed of albumin and globulin, had poorer quality than gluten (gliadin and glutenin) (Liu et al. 2015) and wheat germ flour in bread with diluted gluten protein in dough and formed weaker dough (Sun et al. 2015).

The bread samples with the lowest amount of WF (1 $[35 \mathrm{WF}+0.60 \mathrm{FR}], 2[35 \mathrm{WF}+2.60 \mathrm{FR}]$ and $5[24.64 \mathrm{WF}+$ $1.60 \mathrm{FR}])$ have chewiness values substantially equal to each other and lower than other samples $(P \leq 0.05)$. Bread dough is the system with interaction between different components incorporated that may cause different effects, as in similar work (Bárcenas et al. 2009), in which three different hydrocolloids were used (arabic gum, pectin and hydroxypropyl methylcellulose), resulting in modification of hydration properties, gluten quality and rheological properties of gluten and starch, depending on the type and concentration used.

\section{Sensory Texture Analysis}

Sensory texture bread parameters are described in Table 3.

Hardness. The results of sensory bread samples' hardness are shown in Table 3, with grades ranging from 3.15 to 5.61 . 
TABLE 3. SENSORY TEXTURE PARAMETERS

\begin{tabular}{|c|c|c|c|c|c|c|}
\hline Sample bread loaves & WF (\%) & FR (\%) & Hardness & Elasticity & Cohesiviness & Chewiness \\
\hline 1 & 35.00 & 0.60 & $3.79^{b c} \pm 1.40$ & $6.21^{\mathrm{ab}} \pm 0.89$ & $6.96^{a} \pm 1.18$ & $48.67^{\mathrm{abc}} \pm 13.17$ \\
\hline 2 & 35.00 & 2.60 & $3.15^{c} \pm 1.25$ & $6.30^{\mathrm{ab}} \pm 1.07$ & $6.88^{\mathrm{ab}} \pm 0.93$ & $45.50^{b c} \pm 10.11$ \\
\hline 3 & 85.00 & 0.60 & $5.61^{a} \pm 0.85$ & $4.25^{c} \pm 1.01$ & $4.50^{\complement} \pm 0.64$ & $64.83^{\mathrm{ab}} \pm 11.21$ \\
\hline 4 & 85.00 & 2.60 & $5.38^{\mathrm{ab}} \pm 0.80$ & $4.71^{b c} \pm 1.08$ & $4.79^{c} \pm 0.86$ & $66.33^{a} \pm 20.43$ \\
\hline 5 & 24.64 & 1.60 & $3.88^{\mathrm{bc}} \pm 1.92$ & $6.83^{\mathrm{a}} \pm 1.34$ & $6.68^{\mathrm{ab}} \pm 1.93$ & $42.67^{c} \pm 16.95$ \\
\hline 6 & 95.35 & 1.60 & $5.33^{\mathrm{ab}} \pm 1.13$ & $4.65^{b c} \pm 1.48$ & $4.57^{c} \pm 0.71$ & $58.33^{\mathrm{abc}} \pm 12.46$ \\
\hline 7 & 60.00 & 0.18 & $4.73^{\mathrm{abc}} \pm 1.19$ & $5.46^{\mathrm{abc}} \pm 1.05$ & $5.42^{b c} \pm 0.84$ & $53.08^{\mathrm{abc}} \pm 12.90$ \\
\hline 8 & 60.00 & 3.00 & $4.50^{\mathrm{abc}} \pm 1.07$ & $5.67^{a b c} \pm 1.35$ & $5.49^{\mathrm{abc}} \pm 1.34$ & $49.67^{\mathrm{abc}} \pm 14.28$ \\
\hline 9 & 60.00 & 1.60 & $4.36^{\mathrm{abc}} \pm 1.22$ & $5.27^{\mathrm{abc}} \pm 1.00$ & $5.90^{\mathrm{ab}} \pm 0.58$ & $56.50^{\mathrm{abc}} \pm 18.65$ \\
\hline 10 & 60.00 & 1.60 & $4.37^{a b c} \pm 1.48$ & $5.33^{\mathrm{abc}} \pm 1.39$ & $5.42^{\mathrm{bc}} \pm 0.70$ & $64.25^{\mathrm{ab}} \pm 22.08$ \\
\hline 11 & 60.00 & 1.60 & $5.01^{\mathrm{ab}} \pm 1.04$ & $4.96^{b c} \pm 1.34$ & $4.95^{c} \pm 1.10$ & $60.67^{\mathrm{abc}} \pm 16.99$ \\
\hline 12 & 60.00 & 1.60 & $4.95^{\mathrm{ab}} \pm 1.24$ & $4.85^{b c} \pm 1.88$ & $4.31^{c} \pm 1.64$ & $58.92^{\mathrm{abc}} \pm 10.36$ \\
\hline $9-12$ & 60.00 & 1.60 & $4.67^{\mathrm{abcd}} \pm 0.96$ & $5.10^{b c} \pm 1.19$ & $5.14^{c} \pm 0.82$ & $60.08^{\mathrm{abc}} \pm 14.73$ \\
\hline
\end{tabular}

Mean \pm standard deviation in the same column followed by different letters are significantly different $(P \leq 0.05)$.Sample breads $9-12$ represent the average among bread loaves from 9 to 12.FR, fat replacer; WF, whole-wheat flour.

Samples 3 (85WF+0.6FR), $4 \quad(85 \mathrm{WF}+2.6 \mathrm{FR}), \quad 6$ $(95.35 \mathrm{WF}+1.6 \mathrm{FR}), 7$ (60WF + 0.18FR), 8 (60WF + 3FR) and $9-12(60 \mathrm{WF}+1.6 \mathrm{FR})$, all $\geq 60 \mathrm{WF}$ presented equal and higher hardness values $(P \leq 0.05)$ than other bread samples $(1 \quad[35 \mathrm{WF}+0.6 \mathrm{FR}], 2 \quad[35 \mathrm{WF}+2.6 \mathrm{FR}]$ and 5 $[24.64 \mathrm{WF}+1.6 \mathrm{FR}])$, thus showing that the variation in the amount of FR was not perceived by judges trained with respect to the hardness parameter.

This result can be ratified observing samples 1 (35WF + $0.6 \mathrm{FR})$ and $2(35 \mathrm{WF}+2.6 \mathrm{FR}) ; 3(85 \mathrm{WF}+0.6 \mathrm{FR})$ and 4 $(85 \mathrm{WF}+2.6 \mathrm{FR}) ; 7(60 \mathrm{WF}+0.18 \mathrm{FR}), 8(60 \mathrm{WF}+3 \mathrm{FR})$ and 9-12 (60WF $+1.6 \mathrm{FR})$ as there was no significant difference $(P \leq 0.05)$ in sensory hardness results from samples with the same content of WF and changes in the fat content replacement. Bread samples 9-12 (60WF + 1.6FR) showed hardness value $(P \leq 0.05)$ equal to bread samples $9(60 \mathrm{WF}+$ $1.6 \mathrm{FR}), 10(60 \mathrm{WF}+1.6 \mathrm{FR}), 11(60 \mathrm{WF}+1.6 \mathrm{FR})$ and 12 $(60 \mathrm{WF}+1.6 \mathrm{FR})$.

Elasticity. The results of sensory elasticity of the bread samples (Table 3) ranged in their grades from 4.25 to 6.83 , similar (4.7 to 7.1) to those found in the study of Koletta et al. (2014) in which white flour bread has been replaced by rye whole meal flour and/or whole meal barley and/or oat bran.

Sample 3 (85WF + 0.6FR) was significantly lower in elasticity than samples 1 (35WF+0.6FR), $2(35 \mathrm{WF}+2.6 \mathrm{FR})$ and $5(24.64 \mathrm{WF}+1.6 \mathrm{FR})$ and was equal in elasticity compared with other samples $(P \leq 0.05)$, regardless of the amount of the FR.

Observing bread samples 1 (35WF $+0.60 \mathrm{FR})$ and 2 $(35 \mathrm{WF}+2.60 \mathrm{FR}) ; 3(85 \mathrm{WF}+0.60 \mathrm{FR})$ and $4(85 \mathrm{WF}+$ $2.60 \mathrm{FR}) ; 7$ (60WF + 0.18FR), 8 (60WF + 3.00FR) and 9-12 $(60 \mathrm{WF}+1.60 \mathrm{FR})$, it appears that there was no significant difference $(P \leq 0.05)$ in the results of sensory elasticity between samples with the same WF content and variation in the content of the FR.

As shown in Table 3, the least hard bread loaves (1: $35 \mathrm{WF}+0.6 \mathrm{FR} ; 2: 35 \mathrm{WF}+2.6 \mathrm{FR} ; 5: 24.64 \mathrm{WF}+1.6 \mathrm{FR}$ and 9-12: $60 \mathrm{WF}+1.6 \mathrm{FR})$, therefore softer, are shown to be more elastic $(P \leq 0.05)$, i.e., with higher elasticity, the same behavior observed in the instrumental analysis.

Cohesiveness. The results of sensory cohesiveness of bread samples are shown in Table 3, with grades ranging from 4.50 to 6.96 , similar (2.8-8.2) to those found in the study of Callejo et al. (2015) where breads were baked with bread wheat and spelt wheat.

Sensory cohesiveness values were shown to be similar to sensory elasticity behavior and results of instrumental cohesiveness and were inversely proportional to the increase in WF.

Chewiness. Sensory chewiness results of the bread samples are shown in Table 3, with grades ranging from 42.67 to 66.33, and similar to sensory hardness, which was also observed between instrumental chewiness and hardness.

\section{Principal Component Analysis and Correlation between Instrumental and Sensory Texture}

To determine the relationship between instrumental (I) and sensory (S) texture assessment, PCA (Kihlberg et al. 2006) and correlation matrix (Bordes et al. 2008) were used.

Figure 1 shows a biplot with the projection of the parameters studied in the PCA and samples, set in the foreground by two factors ( 1 and 2), which describe about 91 and $3 \%$ of variance, respectively. The explained variance in Fig. 1 amounts to $94 \%$. The first and the second axes describe virtually all of the variations in texture (instrumental and sensory). Elasticity (SE and IE) and cohesivity (SC and IC), 
FIG. 1. BREAD SAMPLES' PRINCIPAL COMPONENT ANALYSIS

Biplot between principal component analysis and the projection of the components of the instrumental and sensory bread texture parameters.

FR, fat replacer; IC, instrumental cohesivity; IE, instrumental elasticity; $I \mathrm{H}$, instrumental hardness; IW, instrumental chewiness; SC, sensorial cohesivity; SE, sensorial elasticity; $\mathrm{SH}$, sensorial hardness; SW, sensorial chewiness; WF, whole-wheat flour.

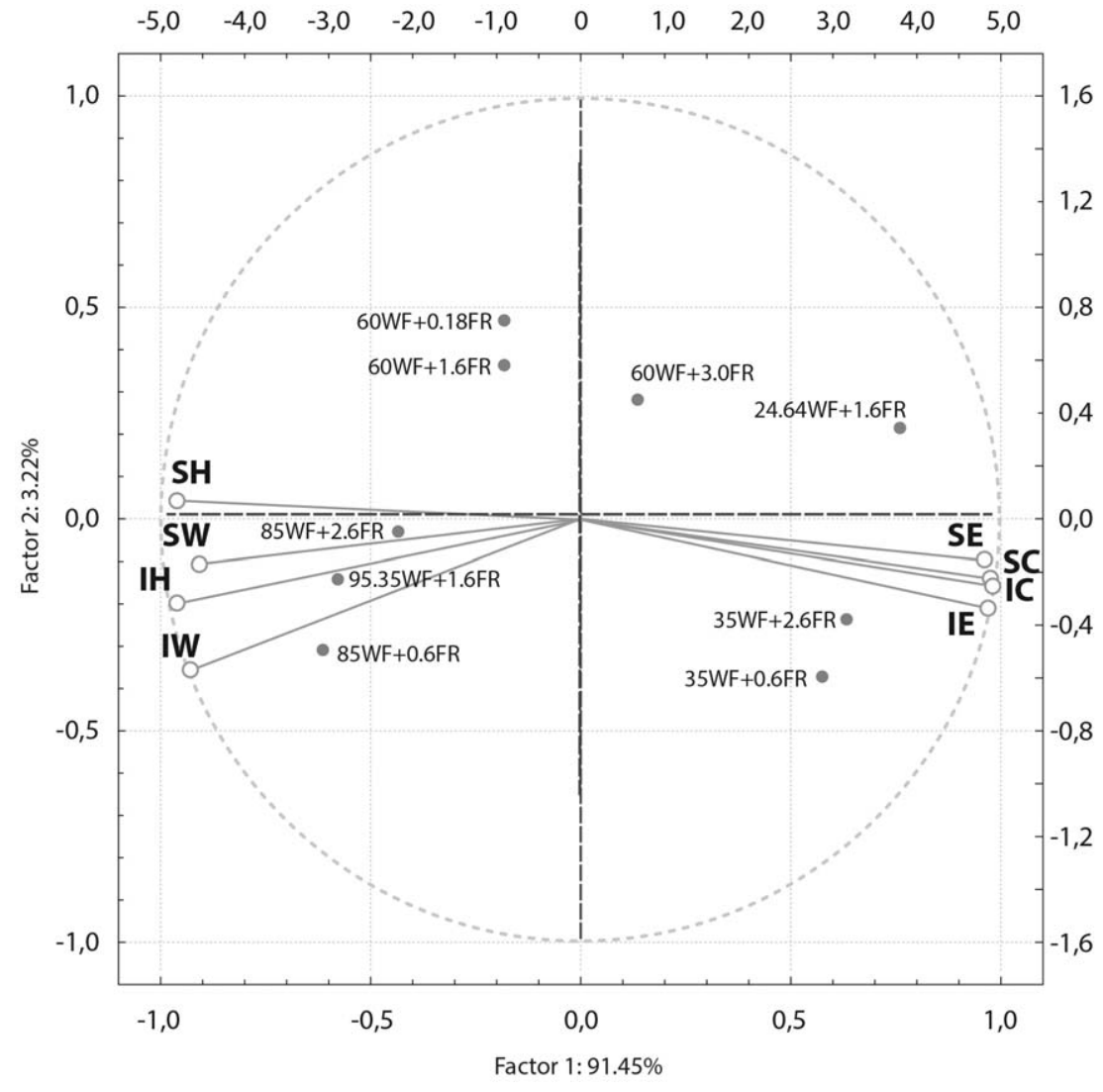

both instrumental and sensorial, were found at the positive end of the first axis. Hardness ( $\mathrm{SH}$ and $\mathrm{IH}$ ) and chewiness (SW and IW), both instrumental and sensorial, were found at the negative end of the first axis and were therefore negatively correlated with samples 1 (35WF+0.6FR), 2 $(35 \mathrm{WF}+2.6 \mathrm{FR})$ and 5 (24.64WF + 1.6FR), with lower levels in WF. Sensory hardness ( $\mathrm{SH})$ was found at the positive end of the second axis. Samples 7 (60WF $+0.18 \mathrm{FR}), 8$ $(60 \mathrm{WF}+3.0 \mathrm{FR})$ and $9-12(60 \mathrm{WF}+1.6 \mathrm{FR})$ were the ones that most strongly contributed to this parameter. On the other hand, instrumental hardness (IH), sensory chewiness (SW) and instrumental chewiness (IW) were found at the negative end of the second axis, while the samples that contributed most to this parameter are the ones with higher WF content: 3 (85WF + 0.6FR), $4(85 \mathrm{WF}+2.6 \mathrm{FR})$ and 6 (95.35WF + 1.6FR).

Besides, Fig. 1 shows the projection of the principal components of the parameters of instrumental and sensory texture compared with the elaborated bread loaves.

Figure 1 shows that the vectors of parameters that are close to each other represent positive parameters that are strongly correlated.

There is a strong positive correlation between the same instrumental and sensory parameters: hardness, elasticity, cohesivity and chewiness. There were also strongly and positively correlated different parameters, such as chewiness and hardness, elasticity and cohesiveness, whether instrumental (I) or sensory (S).

The parameters whose vectors form an angle of $180^{\circ}$, or have this behavior, correlate negatively, as it can be seen between elasticity and hardness; elasticity and chewiness; cohesiveness and hardness; cohesiveness and chewiness, whether instrumental or sensory, as both show the same behavior (Fig. 1).

Factors 1 and 2 represent different forms between instrumental and sensory texture, i.e., the contrast between them.

Some parameters were correlated moderately to factor 1 : IE $(0.97) \times \mathrm{IH}(-0.97)$; SE $(0.96) \times \mathrm{SH}(-0.96)$; IC $(0.98) \times$ IW $(-0.93)$; and SC $(0.98) \times$ SW $(-0.91)$; therefore, the positive parameters showed values similar to the negative parameters.

The unique positive and moderately correlated parameter to factor 2 was SH (0.04), which showed similar value when compared to the negative parameter SE $(-0.09)$. The other parameters correlated to factor 2 were negative: IH $(-0.19)$, IE $(-0.20)$, IC $(-0.15)$, SC $(-0.13)$, IW $(-0.35)$, SW $(-0.10)$. Quadrant II of Fig. 1, which includes bread samples $1(35 \mathrm{WF}+0.6 \mathrm{FR})$ and $2(35 \mathrm{WF}+2.6 \mathrm{FR})$, is associated with cohesiveness and elasticity parameters, both instrumental and sensory. Quadrant III with bread samples 
TABLE 4. CORRELATION MATRIX BETWEEN PARAMETERS OF INSTRUMENTAL AND SENSORY TEXTURE OF THE ELABORATED BREAD LOAVES

\begin{tabular}{lrrrrrrr}
\hline & \multicolumn{1}{l}{ IH } & \multicolumn{1}{l}{ SH } & IE & SE & IC & SC & IW \\
\hline IH & & & & & & & \\
SH & 0.91 & & & & & & \\
IE & -0.91 & -0.90 & & & & & \\
SE & -0.90 & -0.88 & 0.94 & & & & \\
IC & -0.94 & -0.93 & 0.98 & 0.96 & & & \\
SC & -0.92 & -0.96 & 0.97 & 0.91 & 0.97 & & \\
IW & 0.98 & 0.86 & -0.84 & -0.86 & -0.87 & -0.86 & \\
SW & 0.84 & 0.88 & -0.85 & -0.86 & -0.83 & -0.88 & 0.84
\end{tabular}

IC, instrumental cohesivity; IE, instrumental elasticity; IH, instrumental hardness; IW, instrumental chewiness; SC, sensorial cohesivity; SE, sensorial elasticity; SH, sensorial hardness; SW, sensorial chewiness $(P \leq 0.05)$

$3(85 \mathrm{WF}+0.6 \mathrm{FR}), 4(85 \mathrm{WF}+2.6 \mathrm{FR})$ and $6(95.35 \mathrm{WF}+$ $1.6 \mathrm{FR})$ is associated with hardness and chewiness, both instrumental and sensory. In addition, quadrant IV, which is composed of bread samples 7 (60WF $+0.18 \mathrm{FR})$ and 9-12 $(60 \mathrm{WF}+1.6 \mathrm{FR})$, is associated with sensory hardness parameter (Fig. 1).

From the overlay of Fig. 1 (biplot), it can be seen that bread samples 1 (35WF + 0.6FR), $2(35 \mathrm{WF}+2.6 \mathrm{FR})$ and 5 $(24.64 \mathrm{WF}+1.6 \mathrm{FR})$ show the lowest mean for SH because the perpendicular graphical projection on the vector of the $\mathrm{SH}$ variable falls below the origin. Samples $3(85 \mathrm{WF}+$ $0.6 \mathrm{FR}), 4(85 \mathrm{WF}+2.6 \mathrm{FR})$ and 6 (95.35WF + 1.6FR) present the highest means for $\mathrm{SH}$ because the perpendicular graphical projection on the vector of the $\mathrm{SH}$ variable lies above the origin. Moreover, samples 7 (60WF $+0.18 \mathrm{FR})$, 8 (60WF + 3.0FR) and 9-12 (60WF + 1.6FR) show the mean value for the $\mathrm{SH}$ variable because the perpendicular graphical projection on the vector of these $\mathrm{SH}$ variables lies near the origin.

Using PCA, it was observed in this study that there is a strong relationship between instrumental and sensory texture. Further, all correlations presented in the correlation matrix (Table 4) showed that it is possible to describe sensory texture variations through instrumental measurements (as described by Gámbaro et al. 2002, who found that sensory texture attributes were well predicted by TPA), and vice versa, confirming what has been described based on the results in Tables 3 and 4.

\section{CONCLUSIONS}

Instrumental and sensory analysis results showed a good correlation on the textural characteristics of whole-wheat loaves with FR, made at a pilot plant level.

It was observed that below $60 \%$ of WF, the fat replacement levels had no influence on the final texture of the loaves, which in general were softer, more elastic and cohesive. On the contrary, bread loaves with more than $60 \%$ of WF become instrumentally softer as the levels of FR increased. However, increased high WF contents resulted in firmer and more chewable bread loaves.

The use of PCA and the correlation matrix between instrumental and sensory analysis results were effective, showing that the instrumental hardness parameter of bread crumb can be used to predict the final textural quality of the loaves. As confirmed by Rizzello et al. (2011), hardness is often considered as the index of the total textural attributes.

\section{ACKNOWLEDGMENTS}

The authors thank the Fundação de Amparo à Pesquisa e Inovação do Estado de Santa Catarina (FAPESC) for the financial support; Instituto Federal de Educação, Ciência e Tecnologia de Santa Catarina (IFSC) for the availability of instructional time to the volunteers; and sensory analysts for participating.

\section{CONFLICT OF INTEREST}

The authors declared that they have no conflict of interest.

\section{REFERENCES}

AACC INTERNATIONAL. 2000. Approved Methods of the AACC, 10th Ed., American Association of Cereal Chemists, St. Paul, MN.

ALMEIDA, E.L., CHANG, Y.K. and STEEL, C.J. 2013. Dietary fibre sources in bread: Influence on technological quality. LWT - Food Sci. Technol. 50, 545-553.

BÁRCENAS, M.E., O-KELLER, J.D. and ROSELL, C.M. 2009. Influence of different hydrocolloids on major wheat dough components (gluten and starch). J. Food Eng. 94, 241-247.

BLANDINO, M., SOVRANI, V., MARINACCIO, F., REYNERI, A., ROLLE, L., GIACOSA, S., LOCATELLI, M., BORDIGA, M., TRAVAGLIA, F., COÏSSON, J.D. et al. 2013. Nutritional and technological quality of bread enriched with an intermediated pearled wheat fraction. Food Chem. 141, 2549-2557.

BORDES, J., BRANLARD, G., OURY, F.X., CHARMET, G. and BALFOURIER, F. 2008. Agronomic characteristics, grain quality and flour rheology of 372 bread wheats in a worldwide core collection. J. Cereal Sci. 48, 569-579.

BOX, G.E.P. and DRAPER, N.R. 2007. Response Surfaces, Mixtures, and Ridge Analyses, Wiley-Interscience, Madison, Wisconsin.

BRASIL. 2005. Guia Alimentar para População Brasileira. Série A. Normas e Manuais Técnicos. Ministério da Saúde, Secretaria de Atenção à Saúde, Coordenação Geral da Política de Alimentação e Nutrição, Brasília. http://www.sonutricao .com.br/downloads/Guia_Alimentar_Populacao_Brasileira.pdf (accessed August 2014). 
CALLEJO, M.J., VARGAS-KOSTIUK, M. and RODRÍGUEZ-QUIJANO, M. 2015. Selection, training and validation process of a sensory panel for bread analysis: Influence of cultivar on the quality of breads made from common wheat and spelt wheat. J. Cereal Sci. 61, 55-62.

CIVILLE, G.V. and SZCZESNIAK, A.S. 1973. Guidelines to training a texture profile panel. J. Texture Studies 4, 204-223.

COLLAR, C., SANTOS, E. and ROSELL, C.M. 2007. Assessment of the rheological profile of fibre-enriched bread doughs by response surface methodology. J. Food Eng. 78, 820-826.

COLLAR, C., JIMÉNEZ, T., CONTE, P. and FADDA, C. 2014. Impact of ancient cereals, pseudocereals and legumes on starch hydrolysis and antiradical activity of technologically viable blended breads. Carbohydr. Polym. 113, 149-158.

ELÍA, M. 2011. A procedure for sensory evaluation on bread: Protocol developed by a trained panel. J. Sensory Studies 26, 269-277.

FISHER, R. 1918. The correlation between relatives on the supposition of Mendelian inheritance. Trans. R. Soc. Edin. 52, 399-433.

FITZGERALD, C., GALLAGHER, E., DORAN, L., AUTY, M., PRIETO, J. and HAYES, M. 2014. Increasing the health benefits of bread: Assessment of the physical and sensory qualities of bread formulated using a renin inhibitory Palmaria palmata protein hydrolysate. LWT - Food Sci. Technol. 56, 398-405.

FLANDER, L., SALMENKALLIO-MARTTILA, M., SUORTTI, T. and AUTIO, K. 2007. Optimization of ingredients and baking process for improved wholemeal oat bread quality. LWT Food Sci. Technol. 40, 860-870.

GÁMBARO, A., VARELA, P. and GIMÉNEZ, A. 2002. Textural quality of white pan bread by sensory and instrumental measurements. J. Texture Studies 32, 401-413.

GÓMEZ, M., RONDA, F., BLANCO, C.A., CABALLERO, P.A. and APESTEGUÍA, A. 2002. Effect of dietary fibre on dough rheology and bread quality. Eur. Food Res. Technol. 216, $51-56$.

GUARDA, A., ROSELL, C.M., BENEDITO, C. and GALOTTO, M.J. 2004. Different hydrocolloids as bread improvers and antistaling agents. Food Hydrocolloids 18, 241-247.

HEENAN, S.P., DUFOUR, J., HAMID, N., HARVEY, W. and DELAHUNTY, C.M. 2008. The sensory quality of fresh bread: Descriptive attributes and consumer perceptions. Food Res. Int. 41, 989-997.

KIHLBERG, I., OSTROM, A., JOHANSSON, L. and RISVIK, E. 2006. Sensory qualities of plain white pan bread - influence of farming system, year of harvest and baking technique. J. Cereal Sci. 43, 15-30.

KOKINI, J.L. 1985. Fluid and semi-solid food texture and texture-taste interactions. Food Technol. 39, 86-94.

KOLETTA, P., IRAKLI, M., PAPAGEORGIOU, M. and SKENDI, A. 2014. Physicochemical and technological properties of highly enriched wheat breads with wholegrain non wheat flours. J. Cereal Sci. 60, 561-568.
KRBI, B., URII-MLADENOVI, N. and CVEJANOV, J. 2005. Principal component analysis of trace elements in Serbian wheat. J. Agric. Food Chem. 53, 2171-2175.

LASSOUED, N., DELARUE, J., LAUNAY, B. and MICHON, C. 2008. Baked product texture: Correlations between instrumental and sensory characterization using Flash Profile. J. Cereal Sci. 48, 133-143.

LI, J. and NIE, S. 2015. The functional and nutritional aspects of hydrocolloids in foods. Food Hydrocolloids doi:10.1016/j.foodhyd.2015.01.035.

LIU, C., LIU, L., LI, L., HAO, C., ZHENG, X., BIAN, K., ZHANG, J. and WANG, X. 2015. Effects of different milling processes on whole wheat flour quality and performance in steamed bread making. LWT - Food Sci. Technol. 62, 310-318.

LOPES, L.F.D. 2001. Análise de componentes principais aplicada à confiabilidade de sistemas complexos. 121 p. Tese (Doutorado em Engenharia de Produção) - Centro Tecnológico, Universidade Federal de Santa Catarina, Florianópolis.

LUCCA, P.A. and TEPPER, B.J. 1994. Fat replacers and the functionality of fats in foods. Trends Food Sci. Technol. 5, 12-19.

MARTIN, M.L., ZELEZNAK, K.J. and HOSENEY, R.C.A. 1991. A mechanism of bread firming. I. Role of starch swelling. Cereal Chem. 68, 498-503.

MEHTA, K.L., SCANLON, M.G., SAPIRSTEIN, H.D. and PAGE, J.H. 2009. Ultrasonic investigation of the effect of vegetable shortening and mixing time on the mechanical properties of bread dough. J. Food Sci. 74, E455-E461.

MIYAZAKI, M., MAEDA, T. and MORITA, N. 2005. Starch retrogradation and firming of bread substituted with hydroxypropylated, acetylated and phosphorylated cross-linked tapioca starches for wheat flour. Cereal Chem. 82, 639-644.

MIYAZAKI, M., VAN HUNG, P., MAEDA, T. and MORITA, N. 2006. Recent advances in application of modified starches for breadmaking. Trends Food Sci. Technol. 17, 591-599.

O'BRIEN, C.M., MUELLER, A., SCANNELL, A.G.M. and ARENDT, E.K. 2003. Evaluation of the effects of fat replacers on the quality of wheat bread. J. Food Eng. 56, 265-267.

ORO, T. 2013. Adaptação de Métodos para Avaliação da Qualidade Tecnológica de Farinha de Trigo Integral. 2013. 157 p. Tese (Doutorado em Ciência dos Alimentos) - Centro de Ciências Agrárias, Universidade Federal de Santa Catarina, Florianópolis.

RIZZELLO, C.G., CASSONE, A., CODA, R. and GOBBETTI, M. 2011. Antifungal activity of sourdough fermented wheat germ used as an ingredient for bread making. Food Chem. 127, 952-959.

ROSELL, C.M. and SANTOS, E. 2010. Impact of fibers on physical characteristics of fresh and staled bake off bread. J. Food Eng. 98, 273-281.

RUBEL, I.A., PÉREZ, E.E., MANRIQUE, G.D. and GENOVESE, D.B. 2015. Fibre enrichment of wheat bread with Jerusalem 
artichoke inulin: Effect on dough rheology and bread quality. Food Struct. 3, 21-29.

SEYER, M. and GÉLINAS, P. 2009. Bran characteristics and wheat performance in whole wheat bread. Food Sci. Technol. 44, 688-693s.

SHALINI, K.G. and LAXMI, A. 2007. Influence of additives on rheological characteristics of whole-wheat dough and quality of chapatti (Indian unleavened flat bread). Part I - hydrocolloids. Food Hydrocolloids 21, 110-117.

SKARA, N., NOVOTNI, D., CUKELJ, N., SMERDEL, B. and CURIC, D. 2013. Combined effects of inulin, pectin and guar gum on the quality and stability of partially baked frozen bread. Food Hydrocolloids 30, 428-436.
SUN, R., ZHANG, Z., HU, X., XING, Q. and ZHUO, W. 2015. Effect of wheat germ flour addition on wheat flour, dough and Chinese steamed bread properties. J. Cereal Sci. 64, 153-158.

SZCZESNIAK, A.S. 1963. Classification of textural characteristics. J. Food Sci. 28, 385-389.

SZCZESNIAK, A.S. 1987. Relating sensory textural attributes of corn tortilla to some instrumental measurements. J. Texture Studies 18, 1-15.

SZCZESNIAK, A.S. 2002. Texture is a sensory property. Food Qual. Prefer. 13, 215-225.

VALENZUELA, A. and SANHUEZA, S. 2008. Lípidos estructurados y los sustitutos de grasas: Los lípidos del futuro. Aceites Grasas. Tomo XVIII 3, 532-540. 